\title{
Tutorship In University Educational Activity
}

\author{
Olga V. Razumova \\ Kazan Federal University, N.I. Lobachevsky Institute of Mathematics and Mechanics \\ Elena R. Sadykova \\ Kazan Federal University, N.I. Lobachevsky Institute of Mathematics and Mechanics \\ Aliya A. Shakirova \\ Kazan Federal University, Institute of Psychology and Education
}

\begin{abstract}
The relevance of the study is conditioned by the fact that at the present time, due to the changes in political, social and economic spheres of Russian society, special demands are required for a future expert, a graduate of a higher school. Most scholars are inclined to believe that modern society requires the rethinking of higher education development concepts, the provision of the focus on a competent combination of education, research and an individual upbringing process.

Upbringing work at the university has repeatedly been the subject of pedagogical research, but at the same time, the problems related to the specifics of student upbringing achievement to the level of aspiration for self-education through the use of modern educational technologies remain insufficiently studied.

The article clarifies the concepts of "self-education", "tutor support" within the paradigm of education by creating the conditions for the self-actualization of an individual, humanization and democratization of the teacher's and trainees' relations learning among themselves; they describe the stages of experimental work on the implementation of the Pedagogical Support Program for students in order to introduce them to self-education.

The following methods were used in the study: theoretical methods (the analysis of psychological, pedagogical literature, mass study and generalization of advanced pedagogical experience, pedagogical modeling) and empirical methods (pedagogical observation, conversation, questioning, interviewing and testing).

The obtained materials of the study can be of interest both for educators of higher educational institutions, and for the experts in secondary vocational education and the teachers of educational centers.
\end{abstract}

Keywords: tutor, tutor support, educational process, self-education, Tutorial support program.

\section{Introduction}

According to the Federal Law "On Education in Russian Federation," the goal of higher education is the intellectual, cultural, and moral development of an individual [6]. To achieve this goal, modern researchers develop appropriate concepts of higher education development, providing a competent combination of education, research and an individual education process.

It should be noted that the process of upbringing becomes effective only when a student demonstrates the desire for self-education, for a careful work on himself. The achievement of this level of student upbringing, in our opinion, is impossible without the use of modern educational technologies based on the recognition a student as a person, his personality, the importance of his personal problems.

The authors of the article emphasize that in practical activities the achievement of the main goal, namely the upbringing of a person capable of self-improvement, is promoted most effectively by such a pedagogical position as tutoring, a special type of humanitarian pedagogical support.

The aim of the study is to describe the stages of the experimental work on the implementation of the Pedagogical Support Program for students with to introduce them to self-education. 


\section{Materials and methods}

In the course of the study, the following approaches and methods were used: the systematic approach to reveal the nature of the problem; classification, systematization, the generalization of pedagogical experience on the problem under study; observation, comparison, questioning; the analysis of the obtained results.

The study was conducted with the students of the pedagogical department at the Institute of Mathematics and Mechanics named after N.I. Lobachevsky of Kazan (Privolzhsky) Federal University.

\section{Results and discussion}

In modern pedagogical science, the very concept of "upbringing" is being refined $[2,4,7,8,16]$. According to Y. Fokin, the upbringing at the university is "a special work of university staff aimed at students' belief system development, moral standards and general cultural qualities provided by the education they receive" [7]. It should be noted that the process of upbringing becomes effective only when a student demonstrates the desire for self-education, for a careful work on himself.

The achievement of this level of student upbringing, in our opinion, is impossible without the use of modern educational technologies. The basis of modern technologies of upbringing is represented by leading ideas $[4,5,8]$. L.I. Malenkova examines and summarizes the following ideas: "the transition from the paradigm of education as the formation of personality in the command-administrative system of relations to the paradigm of education as the creation of conditions for an individual self-actualization; the humanization and the democratization of the relations between a teacher and students studying among themselves; the possibility to choose educational technologies, variational educational methods, means and organizational forms; the possibility of experimental work for teachers, etc." [4]

The considered ideas are united by the fact, that they are all based on a student's recognition as a person, his personality, the importance of his personal problems. In our opinion, this approach is fundamental in the process of education, which leads to self-education.

In the scientific pedagogical literature various approaches to "self-education" concept are considered. Analyzing the interpretations of this concept by such scientists as V.I. Vdovyuk, G.M. Kodzhaspirova, A.Yu. Kodzhaspirova, V.G. Maralova et al., we come to the definition of self-education as the process of conscious activity aimed at one's personality improvement $[2,5,8]$.

The authors of the article emphasize that in practical activities the achievement of the main goal, namely the upbringing of a person capable of self-improvement, is most effectively promoted by such a pedagogical position as tutoring, a special type of humanitarian pedagogical support. The features of a tutor at the university were studied by M.S. Bernstein, N.K. Goncharov, T.A. Ilyina, T.M. Kovaleva et al. $[3,11-15]$. We adhere to the definition of tutor support concept, proposed by E.A. Sukhanova, A.G. Chernyavskaya, who view it as a special way of educational activity, in the process of which a student performs educational activities, and a tutor creates the conditions for its implementation and comprehension [1]. Tutor support consists in the organization of a student education process, which is built on a permanent reflexive correlation of his achievements with the existing interests and aspirations. Tutor support provides ample opportunities for the upbringing process and is a powerful factor for a high quality of higher professional education achievement.

The tasks of the tutor include the accompanying of the student in the process of an individual program development aimed at the goal achievement independently set by a trainee. In the opinion of T.M. Kovaleva, a tutor must create life situations in which it would be possible for a student to show his cognitive initiatives and interests; in his activity, a tutor must use every element of the social and cultural environment, which carries a certain educational effect [3].

It should be noted that mainly in foreign and Russian higher education institutions, tutorial support is organized in the field of educational activities. Little attention is paid to educational process support [1, 915]. 
In Kazan (Volga region) Federal University the Program for the implementation of tutorship support in the educational process of the university has been implemented since 2012. The leading idea: the inclusion of imitative and non-imitative gaming educational technology in the tutorial support will determine the process of self-education of students, will serve as a source for the a personality development. The leading principles are the following ones: the principle of strategic orientation, which involves the determination of a student development strategy in the long term; the principle of a reflexive orientation aimed at reflexive skill development among the participants in the process; the principle of cooperation, which is the interaction of a tutor and a student with the purpose of the developed individual educational program implementation.

The students of different age categories participate in the experiment (I-IV training courses). At each age level tutorial support consists of the following stages: diagnostic-motivational; design; implementation; analytical (reflexive).

At the first diagnostic-motivational stage, using special methods and techniques (questionnaires, tests), a group of students (mostly the sample encompasses the first year of bachelor's degree) is revealed, showing the interest in self-education, understanding its importance in personal and professional development and wishing to engage in self-education. The results of the diagnostics carried out at the beginning of the experimental work showed that some students, knowing well in what direction they need to carry out self-education, do not have the necessary information about the organization of this process (group A), the other part of the students are familiar with the basic methods of self-education, but comprehend their own individual characteristics that require adjustment insufficiently (group B).

With the aim of introduction the students to self-education, the Program of step-by-step tutorial support was developed, taking into account the identified features of first-year students. The program includes both group (tutorial consultation with the elements of conversation, tutorial) and individual (tutorial consultation) forms of pedagogical support.

The main objectives of the motivational phase are the development and the stimulation of motivation for self-education among the students; the identification of prospects for joint work in this direction. In particular, the content of group tutorials includes a video demonstration about the outstanding circus artist Valentin Dikule; the conversations about an accident in the circus during the performance of the most complicated stunt and further healing of the artist; the discussion of the answers to the following questions: which individual features of the famous circus promoted physical healing? Do you have these characteristics? (the questions are directed mainly to group B); which, in your opinion, is the main achievement of Valentin Dikul, and by what means he achieved it; what role self-education played in the revival of the legendary artist? How can you characterize the process of self-education? (questions are directed mainly to group A).

The main objectives of the classes during the design phase, carried out at the second year of education in the university of the specified group of students, is the individual counseling on the creation of the informational portfolio "What am I?" by a student. The information portfolio "What am I?" is aimed at data collection on the personal characteristics of a student, as well as on the qualities that the student would like to cultivate in himself. It should be emphasized that the teacher-tutor should strongly support the aspiration of the students at this stage to find their own original way of portfolio creation. Ultimately, the content of the portfolio varies for each student, but the main elements are the following ones: a short autobiography, the characteristics of school teachers and the academic curator, the originals and the copies of appreciation letters, etc., as well as the copies of diplomas on additional education (artistic, musical and etc.).

Within the framework of the design phase, the analysis of the information portfolio created by the student is carried out, with the emphasis on personal qualities that are desirable. Here it is important to learn from a student about the ideas that he already has, how to start the process of self-education, which activities are necessary for this, and together to develop an appropriate individual trajectory with the student together. 
The implementation phase covers the third and the fourth years of the students' education at the educational institution. The main objectives of this stage are the following ones: the implementation of the type of activity by the student, through which he wants to cultivate the desired quality; Oral presentation during classes with the obtained results. Classes are organized via imitative and noninteractive interactive educational technologies: business and role games, trainings, brainstorming sessions, etc. It should be noted that most of them are organically integrated into the educational process of students. For example, the fear of speaking to a large audience is overcome by students as the result of participation in the business game "The Lesson of Mathematics" as a teacher in the framework of the academic discipline "Methodology for Teaching Mathematics"; the desire to acquire leadership qualities is also realized during thematic "brain storms" in the above-named discipline, etc.

At the implementation stage, individual counseling is provided to create a presentation portfolio "Such a Man I Became" by a student. The presentation portfolio "Such a Man I Became" is an addition to the created thematic portfolio "What am I?" and contains visual evidence of the results obtained by the student.

The final stage in the implementation of the Tutorial support program for students on their joining in selfeducation is the analytical (reflexive) stage. They conduct classes aimed at the student's past path reflexion, the results achieved throughout the entire learning process. In the course of an individual tutor consultation, the possible future collaboration of the student and the tutor within the framework of the magistracy is planned.

\section{Conclusions}

The results of the final diagnosis showed that all the students participating in the experiment clearly understood the information on the process of self-education, began to imagine well in which direction they need to carry out self-education, comprehend their own individual characteristics that require further correction.

\section{Summary}

Thus, in general, the tutoring in the educational process allows a student to build his own development trajectory. It is also undoubted that tutoring in comparison with other resources that increase the quality of upbringing and education, education and training, most fully reveals the potential of a student and, thus, leads to the development of a highly qualified expert.

\section{ACKNOWLEDGEMENTS}

The work is performed according to the Russian Government Program of Competitive Growth of Kazan Federal University.

\section{References}

1. Gorodetskaya N.I. Tutor support of remote training of teachers in the system of postgraduate education: the dissertation by the candidate of pedagogical sciences: 13.00.08 / N.I. Gorodetskaya; [Place of defense: Nizhegor. state. ped. un-ty]. - Nizhny Novgorod, 2010. - 237 p. [Electronic resource]. Access mode: http:/ /lib.ua-ru.net/diss/cont/387799.html (Reference date: 4.03.2018).

2. Kodzhaspirova G.M., Kodzhaspirov A.Yu. Dictionary of Education / G.M. Kodzhaspirova, A.Yu. Kodzhaspirov. - Moscow: Mart; Rostov on/D: March, 2005. - 448 p.

3. Kovaleva T.M. Profession "tutor" / T.M. Kovaleva, E.I. Kobyshcha, S.Yu. Popova, A.A. Terov, M.Yu. Cheredilina. - M. - Tver: SFC-office, 2012. - 246 p.

4. Malenkova, L.I. Theory and the methods of education. Textbook / L.I. Malenkova. - M.: Pedagogical Society of Russia, 2002. - 480 p.

5. Maralov V.G. Fundamentals of self-knowledge and self-development: Textbook for the stud. of ped. institutions. / V.G. Maralov. - 2nd ed., - Moscow: Publishing Center "Academy", 2004. - 256 p. 
6. Parliamentary hearings "On the status and the prospects of higher education development in Russian Federation", Moscow, February 18, 2016 [Electronic resource]. Access mode: http://tgmu.ru/.../rekomendatsii-uchastnikov-parlamentskih-slushaniy-po-teme-o-sostoyanii-iperspektivah-razvitiya-vysshego-obrazovaniya-v-rossiyskoy-federatsii.pdf?1456269147 (Reference date: 28.03.2018).

7. Fokin Yu.G. Teaching and education in higher education: Methodology, goals and content, creativity: Textbook for university students / Yu.G. Fokin. - Moscow: Publishing Center "Academy", 2002. - 224 p.

8. Khuziakhmetov, A.N. Education and socialization of a person / A.N. Khuziahmetov, D.Ya. Sharipova // Innovative technologies in education: the collection of international scientific-educational conf. Kazan: TRI "School", 2017. - pp. 290-296.

9. Aleven, V., McLaren, B., Roll, I., Koedinger, K. Toward Meta-cognitive tutoring: A model of help seeking with a cognitive tutor // International Journal of Artificial Intelligence in Education. - 2006. Volume 16, Issue 2. - Pp. 101-128.

10. Hao, Q., Branch, R.M., Jensen, L. The Effect of Precommitment on Student Achievement Within a Technology-Rich Project-Based Learning Environment // TechTrends. - 1 September 2016. Volume 60, Issue 5. - Pp. 442-448.

11. Hrastinski, S. Cleveland-Innes, M., Stenbom, S. Tutoring online tutors: Using digital badges to encourage the development of online tutoring skills // British Journal of Educational Technology. January 2018. - Volume 49, Issue 1. - Pp. 127-136.

12. Kopp, B., Matteucci, M.C., Tomasetto, C. E-tutorial support for collaborative online learning: An explorative study on experienced and inexperienced e-tutors / / Computers and Education. - January 2012. - Volume 58, Issue 1. - Pp. 12-20.

13. Novikova, S.V., Sosnovsky, S.A., Yakhina, R.R., Valitova, N.L., Kremleva, E.S. The specific aspects of designing computer-based tutors for future engineers in numerical methods studyin // Integration of Education. - April-June 2017. - Volume 21, Issue 2. - Pp. 322-343.

14. Valeeva, R.A. Alternative education: Comparative study of the American, Russian and Kazakhstan experience / R.A. Valeeva, D.I. Vafina, A.A. Bulatbayeva // Mathematics Education. - 2016. Volume 11, № 1. - Pp. 317-325.

15. Valeeva, R.A., Vafina, D.I. Comparative study of American and Russian students' attitude towards alternative education // Life Science Journal. - 2014. - Volume 11(12s). - Pp. 821-824.

16. Yarullin. I.F, Nasibullov, R.R, Khuziakhmetov, A.N, Nasibullova, G.R. Organizing moral education for teenagers in the course of humanitarian subjects / / Man in India. - 2017. - Volume 97, Issue 14. - Pp. 349-357.

Khuziakhmetov A.N. The course of lectures on pedagogy: Textbook for high schools. Kazan: Publishing house "Matbugat yorty", 2000. 374 p.

Bernstein M.S. Individual character of teaching learning and individualization (based on materials from the USA) // Issues of psychology. 1975. №2. pp. 136-147.

Goncharov N.K. Fundamentals of pedagogy / N.K. Goncharov. - Moscow: GUPI of RSFSR Ministry of Education, 1947. - 408 p. 